811.163.41'282.3(497.11-15)

811.163.41'367.625

https://doi.org/10.18485/sj.2021.26.1.26

СЛАВОљУБ 3. МАРКОВИТ

Филолошка гимназија

Београд
Оригинални научни рад

Примљен: 10. 11.2020.

Прихваћен: 12. 1. 2021.

\title{
О ОБЛИЧКОЈ ИНТЕРФЕРЕНЦИЈИ ГЛАГОЛА У ИЈЕКАВСКИМ ГОВОРИМА ЗАПАДНЕ СРБИЈЕ
}

У раду су сагледане маркантне особености конјугацијских типова у говорима западносрбијанског ијекавског комплекса. Обимна дијалекатска грађа обухваћена је и анализирана применом дескриптивног и контрастивног аналитичког метода. Испитивано дијалекатско подручје расветљавано је из више углова, а примарни су следећи: лексичка заступљеност и обличка разуђеност глаголских категорија, унутрашња диференцијација области, поређења са одговарајућим приликама у другим сродним говорима. У спроведеним аналитичким прегледима налазимао упориште за следећи закључак. Осетан број изражајних херцеговачких дијалектизама (облика, алтернација) или је нискофрквентан (нпр. образац наређивати - наређивам, ликови типа давам, познавам, форме реда раду, љубу и сл.) или је незасведочен (нпр. имп. *виђ, трп. прид. *чуно, инф. * обаћи или пак *каживати и сл.). Ипак, укупно узевши, разлике остају у сенци сличности - западносрбијанско ијекавско подручје не излази из оквира доброг херцеговачког просека.

Кључне речи: глаголи, конјугација, корелације, ијекавски, херцеговачки 
Карта испитиваног подручја са мрежом испитиваних насеља ${ }^{1}$

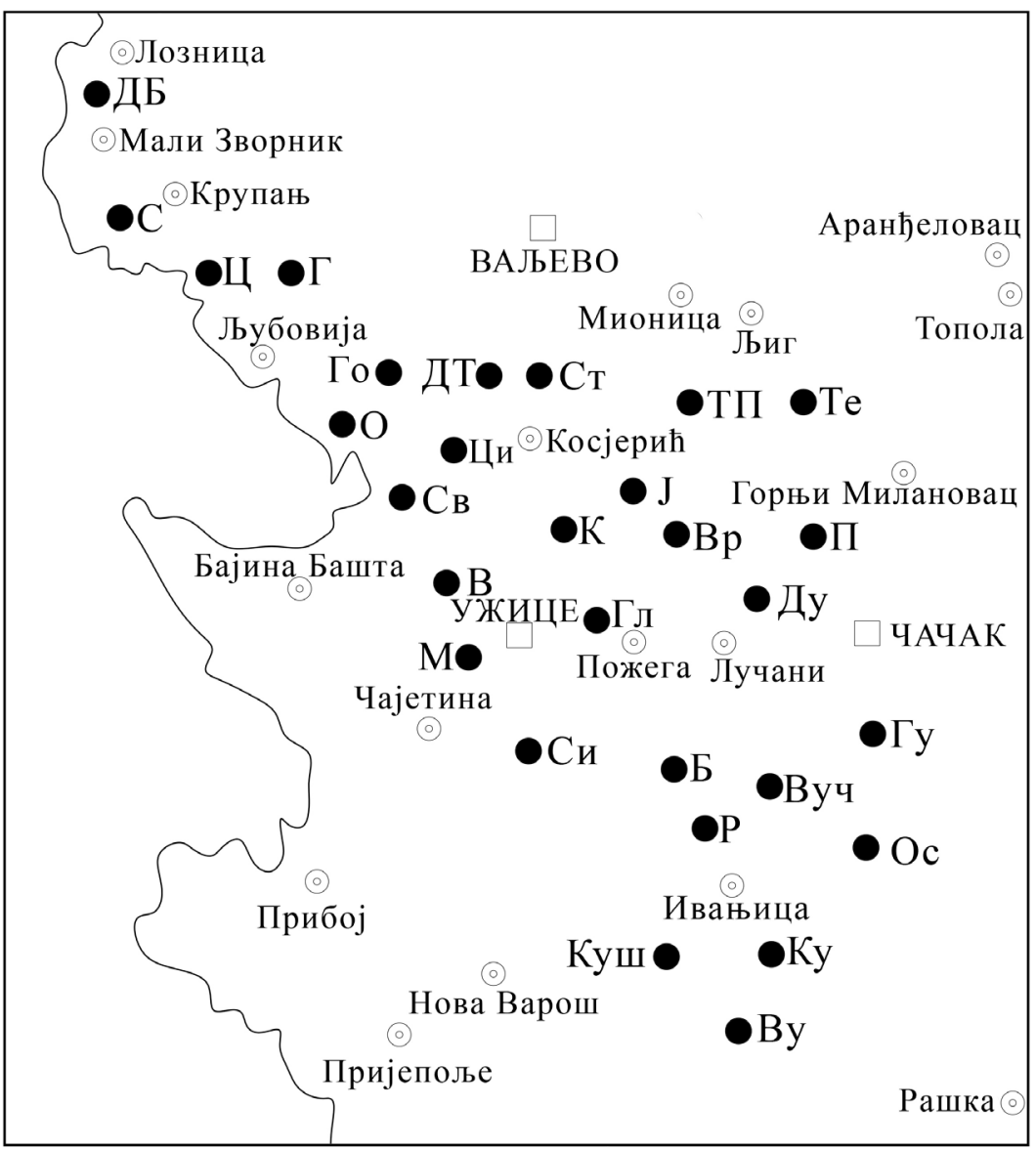

Мрежа испитиваних насеља - списак и скраћенице: (Г)рачаница, (Д)оња (Б)орина - ДБ, (О)клетац, (С)акар, (Св)ојдруг, (Ц)рнча (подринска насеља); (В)олујац, (Вр)нчани, (Гл)умач, (Го)дечево, (Д)оњи (Т)аор - ДТ, (Ј)ежевица, (К)аран, (Ст)ојићи, (Т)ометино (П)оље - ТП, (Ци)коте (насеља Ужичке Црне горе); (П)ријевор, (Т)еочин (таковска насеља); (Вуч)ковица, (Гу)беревци, (Ду)чаловићи, (Ос)оница (драгачевска насеља); (Ву)чак, (Б)огојевићи, (Р)адаљево, (Ку)маница, (Куш)ићи (моравичка насеља); (М)ачкат, (Си)рогојно (златиборска насеља).

${ }^{1}$ Током рада, уз засведочене примере, користићемо скраћенице - почетне делове назива села издвојене у заградама. Дијалекатски подаци преузимани из објављених монографија и радова других аутора праћени су одговарајућим напоменама у заградама и фуснотама. 


\section{І. УВОДНА НАПОМЕНА}

1. У раду су превасходно сагледане упечатљиве особености обличке интерференције глагола у говорима западносрбијанског источнохерцеговачког поддијалекта. ${ }^{2}$ Управо стога глаголски облици нису представљени интегрално и оделито, већ категоријски сврсисходно, кроз њихова системска садејста, кроз процене постојаности, природе и интензитета њихових међусобних корелација. Подесан методолошки оквир за такво сагледавање конјугацијских типова свакако је аналитичко прегледање глаголских категорија и појединачних форми по глаголским врстама. Обиман корпус релевантне дијалекатске грађе разврстан је према Стевановићевој варијанти Белићеве класификације глагола. ${ }^{3}$

\section{II. ПРЕГЛЕД ГРАЂЕ}

\section{1) Глаголи I врсте}

\section{a. О појединим облицима}

2. П р е з е н т. а) Деловањем аналогије, глаголи са основом на $-\kappa,-2,-x$ имају у 3 . л. пл. готово доследно тзв. измењену, палатализовану основу: ви́ч $\bar{y}$

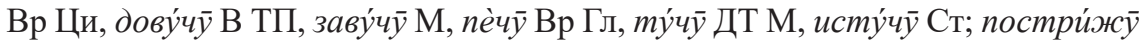
ce $\mathrm{B} ; в \dot{p} m \bar{y} \Gamma \mathrm{C}, o в \dot{p} m \bar{y} \mathrm{C}{ }^{4}$

Стандардни облици, ликови типа обуку, спорадично се јављају на подручју србијанског Полимља (Николић 1991: 431).

б) Презентска парадигма гл. моћи изгледа овако:

1. л. сг. мӧгу Вр Гл Го, мо̀гу Вр Вуч, мӧрем Д, мо̆жем В Си, не мо̀гу Ку Куш С, нѐ могу Куш Св, нѐ морем ДБ Ц, нѐ можем В М Ц;

2. л. сг. мӧжеш Г, мӧреш Св, нѐ можеш $\mathrm{Bp}$, нѐ мореш $\mathrm{B}$, мӧш $\mathrm{Bp}$, нѐ мош В Гл;

3. л. сг. мӧже Гл Го ДТ (исп. и мӧже ДТ М С), мӧрё ДБ О С Св, мӧре Св Ц, нѐ може Вр Гл Го (исп. и нѐ може̄ О С), нѐ море̄ О С Св, нѐ море Ц;

1. л. пл. мӧжемо О С Си, мӧремо О Св, нѐ можемо Гл Го Ј, нѐ моремо Г С Св;

2. л. пл. мӧжете $\mathrm{B} \mathrm{Bp} \mathrm{C}$, мӧрете С Св Ц, нѐ можете Св К Ст, нѐ морете Г М;

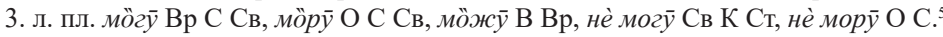

Ликови са -же ( $\leftarrow *$-ге) заступљени су на целом подручју. Облици са -ре $\leftarrow$-же маркантно су обележје јужнијих и западнијих западносрбијанских

${ }^{2}$ Ијекавски изговор је маркантно обележје западносрбијанских говорних типова који се простиру на замашном подручју од Гучева до Јавора, од Сувобора до Гиљеве планине (Марковић 2012: 460).

${ }^{3}$ Стевановић 1975: 328-336.

${ }^{4}$ Интересантно је да у суседном и сродном обаћком говору (босанско Подриње) постоји само лик вуку и сл. (М. Симић 1978: 82).

${ }^{5}$ Доминација ликова са -ре својствена је и неким сродним црногорским говорима, исп.: Вуковић 1938-1939: 68, Ћупић 1977: 90. 
херцеговачких идиома: србијанског Полимља (Николић 1991: 432), рачанског подручја (Марковић 2013: 341), западнијих насеља Ужичке Црне горе (Марковић 2011: 219-221) и србијанских подринских насеља (Марковић 2012: 219-221).

Облик 2. л. сг. мош фреквентан је у свим сегментима испитиване области;

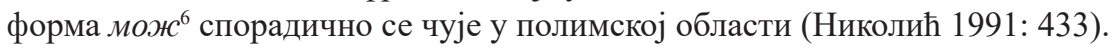

3. Им перати в. За разлику од 3. л. пл. презента (где је редовно вучу и сл.), у императиву аналошки облици са инф. основом на $-\kappa,-2,-x$ готово сасвим изостају. Изузетак имамо само у усамљеном овр́ши К. ${ }^{7}$ Иначе, овде

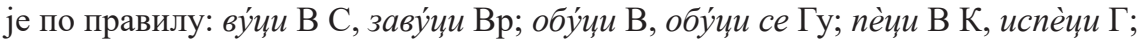
mу́ции $\mathrm{C}$, исту́ци $\mathrm{CT} ;$ постри́зи $\mathrm{B}^{8}$

4. Глаголски придев трпни. а) Глаголи с инф. основом на $c$ најчешће имају аналошке облике: претре́шен $\mathrm{M}$, донѐшен $\mathrm{C} \mathrm{Cт,} \mathrm{донешѐно} \mathrm{Ду} \mathrm{P}$, изнешѐно Св, пренешѐне $\mathrm{B}$, разнешѐно С. Исп., ипак, и унесѐна Ду, унесѐне Б.

б) Код глагола на -з такође налазимо за̀грижена $\mathrm{B}$, довежѐни $\mathrm{C}$, мўжена $\mathrm{O}$, помужена Ду, по̀мужене $\mathrm{M}$ (ређе имамо довѐзен $\mathrm{B}$, довезѐне Ду).

Фреквенцијски омер потврда другачији је у гл. вести: ве́зене ча̀рапе $\mathrm{P}$, ве́зен К Т, наве́зена $\mathrm{P}$, наве́зено Т (исп. ипак и изве́жено Д, ве́жене ча̀рапе $\mathrm{C}$ ).

5. Футур. Када се енклитички облици помоћног глагола хтјети нађу иза инфитива глагола на - $и$, често долази до њиховог срастања: До́ћеш ѝ тй

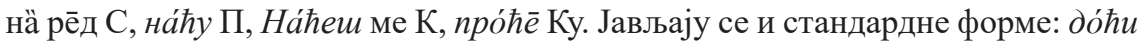
ћу Р, изи́ћи ћу Гу.

\section{б. О односу према другим гл. врстама}

6. На подручју западносрбијанске ијекавске области повелики број глагола има једне облике по I, друге по III, а неке и по I и по III (ређе и по VI) врсти.

7. Глаголи на -сти. а) Глагол дј е с т и /дј е н у т и (прост и сложен). Облици по І врсти: инф. ӥме на̀ђести В; аор. Кӱ-се ђёде? Ду, Кӱ-се ђёдоше? С; р. гл. прид. Кӱ-се ђёла? Р, На̀ђели му йме Са́во М; трп. прид. ођѐвен $\mathrm{P}$, ђевѐна Си, ођевѐни Вуч Гу. Облици по III врсти: инф. у̀ђенути М; аор. Нӓђену му нёкй на́димак Б; през. за̀ђене̄ се ТП, у̀ђенемм ДБ, у̀ђене̄ се Ј; имп. за̀ђени Си, у̀ђени Т; трп. прид. у̀ђенутто Си. Дакле, презентски облици (през. и имп.) имају облике само по III врсти, а инфинитивни (имамо потврде за инф. и аорист) и по I и по III; аорист и трп. придев чешћи су по I него по III врсти.

${ }^{6}$ Према мишљењу проф. Симића мош је пореклом стари оптатив, а мож новија форма настала укрштањем облика може и мош (Симић 1972: 342).

${ }^{7}$ У Горобиљу (моравичко село) засведочено је само Уву́чи кӧла под шу̀nу (Николић 1972: 433); у јужнијим, полимским идиомима облици типа ви́чи су „прилично ретки” (Николић 1991: 433).

${ }^{8}$ У полимским селима забележено је и врси, оврси (Николић 1991: 433). 
б) Глагол (-)пасти има инфинитивне облике доследно по I врсти: инф. näсти $\mathrm{Bp}$, на̀nасти Г, у̀пасти Го; аор. пӓдо $\mathrm{C} \mathrm{Cв}$, у̀мал нѐ падо Ц, näде $\mathrm{B}$, ùcnade $\mathrm{B}$; на̀naдоme Ку, прѐnадок се $\mathrm{M}$; р. гл. прид. пӓо Г Ро, пӓō Г, пӓла Г Си, ѝcnō Б, ѝсnало ДТ и сл.

През. облици су готово редовно по III врсти: пӓднемм ДБ, пӓнеем ДТ,

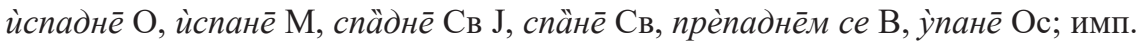
А̀јде реко мѐни до̀пани М. По І врсти имамо само облик презента у примеру

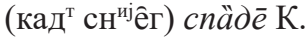

в) Гл. (-)сјести има инф. облике доследно по І врсти: с'ёсти С К, сјёсти Ц; с'ёдок Му, с'ёдо ДБ, с'ёде Св; сјёо С, с'ёла С ДТ, сјёла О С, с'ёли Вуч за̀с'ели Вр и сл.

През. облици јављају се и по I и по III врсти: c'ёдём ТП, c'ёде̄м Го, c'ёде

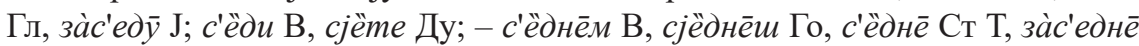
ТП; с'ёдни Р.

У представљеној грађи налазимо упориште за следеће закључке: облици презента по І врсти нису својствени западнијим селима Ужичке Црне горе нити подринским насељима; нејотоване јекавске форме (по свим врстама) јављају се само у западнијим селима испитиване области.

г) Глагол срести. Разврставањем невелике али типски разуђене скупине потврда, дошли смо до следећих закључака. Аорист има облике само по I врсти: срёто га Гл, срёте ме Ци, прѐсретоше ме Вуч. Инф. и р. гл. прид. потврђени су и по I и по VI врсти: срёсти J Ст; срёла Вр Гл, срёло Ос; - предуेсретити $\mathrm{Bp} ;$ срётиंо мѐне Ду (налазимо и срёто̄ га нёђе Ку); додајмо и полимску форму прѐсретили (Николић 1991: 436). Презент се јавља по I, III и VI врсти:

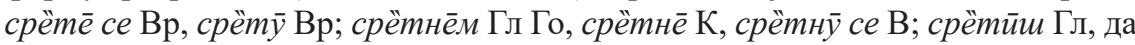
га срётй $\mathrm{J}$, срётйте ДТ.

8. Глаголи на -ћu. а) Глаголи са општим делом (-)бъг- имају стандардне облике; нпр.: инф. по̀бјећи Гл; аор. пӧбјеже Вуч J, по̀бјегосмо М, по̀бјегоше $\mathrm{B} ;$ р. гл. прид. иेзбјего̄ Го, прёбјегла $\mathrm{Bp}$; през. по̀бјегнемм $\mathrm{M}$, прѐбјегнемм Си, прѐбјегнуу К, имп. по̀бјегни К итд.

б) Глагол (-)дићи /(-)дигнути. Инфинитивни облици (инфинитив, аорист, р. гл. придев) доследно су по I врсти: дӥћи Го ДТ (могуће је да форма дигнути случајно није засведочена); по̀дигок К, дйже ДТ, дйгоше Р; дйго̄ Ду, дйгли М. През. и имп. су по ІІІ врсти: дйгнемм Ду Р, дйгнеем Р, по̀дигнём П; дйгни ДТ Си (исп. и дйк се Р и дйщж се Ст).

в) Глагол (-) л е ћ $u$. И овде по І врсти имамо: инф. лѐћи К; аор. лѐже ДТ, лѐгоше М; р. гл. прид. лёго̄ Ст, лѐгла ДТ, лѐгли К. През. је по ІІІ врсти: лёгнём М,

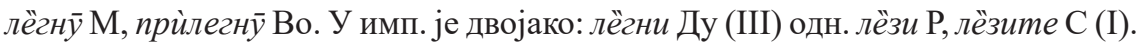


г) Глагол (-) маћи / (-) макнути. Инф. облици су по I врсти: ма̀ћи Св, изма̀ћи Го; ма̀че Г Ос, ӥзмаче Гл; изма̀кли Т, ума̀кла М (и у̀макло ТП); исп. и за̀мче Го. ${ }^{9}$

С друге стране, през. облици редовно су по III врсти: мӑкнеем Вр Гл, на̀макнеем Вуч, смӓкнеемо Т; изма̀кни се ТП, пома̀кни $\mathrm{M}$, пома̀книде̄ се $\mathrm{B}$.

За трп. прид. по I врсти имамо сма̀чен Гл, а по III прѝмакнӯто Ку.

д) Сложени гл. с основом -мог- који се граде од инф. основе доследно су по I врсти: инф. помо̀ћи Гл; аор. занеможе $\mathrm{B}$, помо̀же $\mathrm{M}$; р. гл. прид. по̀мого̄ Гл Го, помо̀лла Вр. И засведочени облици императива су по І врсти: помо̀зи Го, помо̀зите $\mathrm{P}$.

На највећем делу сагледаваног подручја у презенту је двојако (по I и III врсти):

Да ми по̀можееш Ку, по̀може̄ К Ку; по̀могнеем ГТ, по̀могнееш $\mathrm{MP}$, по̀могнее Си. ${ }^{10}$

У подринским насељима сви засведочени облици су по III врсти. ${ }^{11}$

ђ) Глагол пући / пукнути. Засведочени инф. облици су по I врсти: аор. нёшто пӱче $\mathrm{B}$, nӱче коेнопац К, пйкоше ӧ-смија̄ Ду; р. гл. прид. пӱко̄ К, пйкла $\mathrm{M}$ (исп. и на̀nукла $\mathrm{P})$. За през. имамо пӱкне Б, облик по III врсти. ${ }^{12}$

е) Глагол рећи. Сви засведочени инф. облици и облици императива су по I врсти: инф. рѐћи $\mathrm{B}$ Г; аор. рѐко $\mathrm{B}$ Ду, рѐкок $\mathrm{K}$, рёче $\mathrm{B}$ Ц, рѐкосмо Г $\mathrm{P}$, рѐкосте $\mathrm{P}$, рѐкоше $\mathrm{B} ; \mathrm{p}$. гл. прид. рёко̄ $\mathrm{B} \mathrm{Bp}$, рѐкла $\mathrm{B}$, рѐкли Г ДБ, за̀реко̄ се $\mathrm{B} \mathrm{Oc}, \grave{u} з р е к \bar{~}$ ce $\mathrm{K}$, о̀реко̄ се К $\mathrm{P}$; имп. рѐци Гл $\mathrm{C}$, рѐците $\mathrm{M} \mathrm{C}$.

Облици презента су по III врсти (на целом подручју) и по I врсти (у источнијим и јужнијим насељима испитиване области): рёкнеем Г ДБ, рёкнет рёкнё Вуч Ос; рёчём Вр Гл Си, рёчети Ду, рёчее ДД Ми Му Рош, рёчӯ Гл Го Си.

ж) Глагол стићи. Инф. облици су доследно по І врсти: инф. стӥћи Вуч Гу; аор. стйгок ТП, нѐ стиго О, стйгосмо Гу; р. гл. прид. стйго̄ Го Си, стйгла Гл, по̀стиго̄ В. През. облици су по ІІІ врсти: през. стйгнеем Г, стйгнёмо Вр и сл.; имп. прѐстигни Ос.

3) Забележени инф. облици гл. са основом (-)тек- по I су врсти: инф. претѐћи C J, Ёда ли претѐћи штӓ и мѐни Ду; аор. утѐкок Гу, утѐко Гу Ду, утѐкоше Б; р. гл. прид. за̀теко̄ га М Си, затѐкла $\mathrm{C}$ К, истѐкла во̀да ТП. Засведочени облици презента не припадају истој врсти: за̀текне̄ га Оc (III), за̀mечӯ гa B (I).

${ }^{9}$ У пожешком селу Јежевици чује и за̀мћи, по̀мкни и сл. (Николић 1991: 437, бел. 1224).

${ }^{10}$ Овако је и у неким околним сродним говорима, исп. нпр. Пецо 1964: 150, Пижурица 1981: 157.

${ }^{11}$ Тако је и са друге стране Дрине, исп. Симић 1978: 82.

${ }^{12}$ У србијанском Полимљу засведочен је и трпни придев пӱчено (Николић 1991: 438). 
и) Глагол ирћи. Инф. облици су по I врсти: инф. да мо̀же ирићи Б; аор. цреккок ра́де̄ћи Ву, цйче ТП Си, у̀мал нѐ ирче В; р. гл. прид. циркло Си, ирекли да̀бо̄гда̄ Ви. През. облици су, наравно, по III врсти: ирекнемм С, ирекнеммо Си; црекни кат си та̀ка̄ Ци.

\section{в. О другим особенијим глаголима и скупинама глагола I врсте}

9. Глагол ј е с $m$ и: инф. јёсти Г; през. јёдём В Вр, д-ёдёмо М; аор. јёдок М Р, јёдо Г, јёдосмо Бр, јёсмо Си; р гл. прид. јёо Вр Го, јёла Г Ос, јёли Вр Гл; трп. прид. јёдено Вр Го; имп. јёди В, јёдите М, јёте Р; фут. јёшћемо В. Говори се и ѝзјести Си и из'ести У, као и ѝз'едём $\mathrm{P}, \grave{u}{ }^{\prime} \bar{o} \mathrm{Bp}, \grave{u}^{\prime}$ ела Ву, одн. ѝзједермо М, ѝзјо̄ К, ѝзјели Куш и сл.

10. Глагол (-) р а с ти и: инф. pácmu В Ц, пора́сти Го М; през. pácmē Гу J,

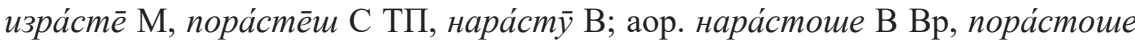
Си; р. гл. прид. ра́сла Ду, до̀ра̄сто̄ ТП, зара́сло В М (оба глагола имају стандардне облике).

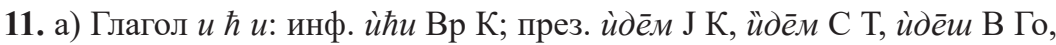

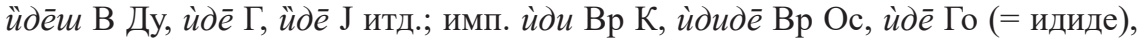
иेдите $\mathrm{B}$, ѝте $\mathrm{C} \mathrm{Cи;} \mathrm{аор.} \mathrm{ѝдок} \mathrm{B}$, ѝेо $\mathrm{B}$ Го, ѝде ли $\mathrm{P}$, ѝдоше $\mathrm{Bp} ; \mathrm{p}$. гл. прид. ѝmо̄ Вр Си, имила В итд.

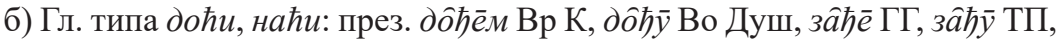

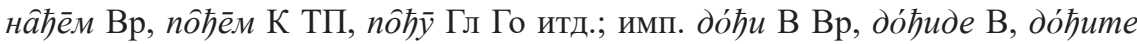

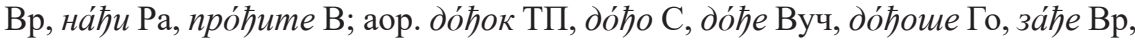
за́ђоме Вр Гл, на́ђок Вр Гл, на́ђо В, nóђе Гл, про́ђе Го; р. гл. прид. до̀mō Г ТП, домшла Го К, за̀шли Го К итд.

в) Гл. типа прићи, сићи (тј. са -u-): през. приิђём ДБ, прйђё Вр Гл, сйђём Гл, cûђȳ П; имп. прúђи В Го, прúђите Гл, сúђи М; аор. при́ђок Вуч Гу Ду, при́ђо ДБ, при́ђоше М Си, си́ђе Ду М, си́ђосмо М; р. гл. прид. прѝто̄ ДД Кр, сѝшли К Си.

На целом подручју спорадично се чују облици лексеме саћи: cáђоме ДБ, càmла Св, сàmле Вуч ${ }^{13} \mathrm{У}$ полимским насељима засведочен је и импф. гл. VI врсте са̀лазили (Николић 1991: 441).

в) Облици гл. $u з и \hbar u$ чешћи су од облика гл. $u з a \hbar u$ : инф. изи́ћu В Св Ц,

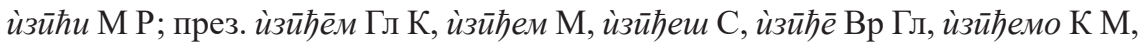

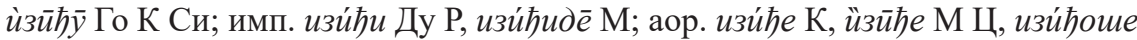
П; р. гл. прид. ѝзишо̄ ДБ, изѝшо̄ К, ѝзишла Ду, ѝзишло К; - инф. иза́ћи В Си, ѝза̄ћи Го; през. ѝза̄ђем К, ѝза̄ђе Ду, ѝза̄ђе $\mathrm{M}$, ѝза̄ђемо К; имп. иза́ђи Р; р. гл. прид. ѝзашо̄ Си, ѝзашла Ри.

${ }^{13}$ Ужичком Подрињу је „си́ћu, cáћu и врло ретко càūћu” (Тешић 1977: 229). 
Примери с нејотованом основом типа приिдемо, сиิде, одн. ѝзйде̄м

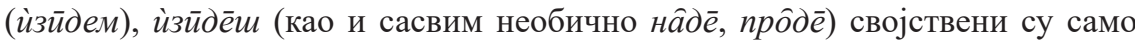
србијанском ијекавском југу, тј. полимској области (Николић 1991: 440-441).

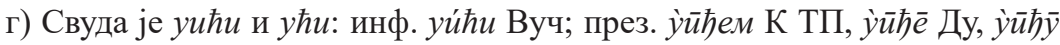

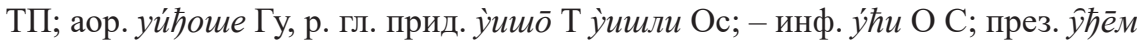

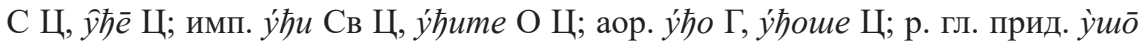
С, у̀шла Гу Р, учшли Г. ${ }^{14}$

д) Глагол от ићи: инф. оти́ћи Вр, оттӥћи В; през. ӧдём К Ци, оิдемм С, ӧде̄ш В Вр, ӧде Вуч Ду, о̆де̄ Вр итд.; имп. оти́ђи Вр, оти́ђите ТП; аор. о̀док

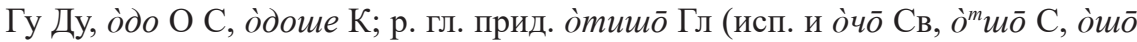
Св, ошли Гл), оттиила Ду.

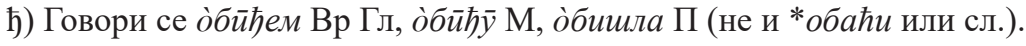

12. Глаголи са основом -нес/-није. Обе могућности, тј. и(ли) једну и(ли) другу, имамо у аористу и трпном придеву: аор. дӧнесе $\mathrm{Bp}$, до̀н $н^{u j} \bar{e} ш е \mathrm{T \Pi}$, принѐсоше Вуч, проेније̄ще $\mathrm{B}$, рӓзнесе $\mathrm{O}$, ра̀знијёше $\mathrm{P}$; трп. прид. донешѐна $\mathrm{K}$, дӧнијетто ТП, унесѐна Ду.

У инф. и р. гл. прид. нису засведочени гл. са основом -нес.

13. Глаголи са основом на $p$. Од гл. са основом на -стр-: през. зӓстрём Гу, прӧстрё Св, ра̀застрёмо Вр; имп. за̀стри $\mathrm{B}$, про̀стри Ду; р. гл. прид. прӧстро̄ Ду; трп. прид. зӓстртто В. Исп. и проेстерём $\mathrm{M}$ (као и ӧтрём се К, ӧтрев; р. гл. прид. ӱтрили Ц).

14. За однос дерати/драти/дријети (и композите) наводимо следеће потврде: инф. дѐрати С Св, одѐрати С; аор. про̀дриіё ТП, за̀дрuіе Ду; р. гл. прид. дёро̄ П СР, зӓдро̄ Р, ӧдро̄ В К (исп. и ӥздера̄ла се С); имп. не дѐри се $\mathrm{B}$.

15. Гл. мријет и и композите имају стандардне облике: инф. мрие́ти

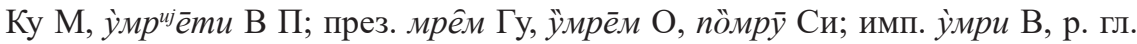
прид. мйо В, ми́ла па жи́вила Ц, ми́ли Гу, ӱмро̄ Гл ТП, ӱмр̄ла М, пӧмр̄ли М; аор. у̀мриंе М Р по̀мр ${ }^{u j} \overline{е ш е ~ Д у . ~}$

16. Од стандарда не одступају ни глаголи са основом на -е (отети, поче-

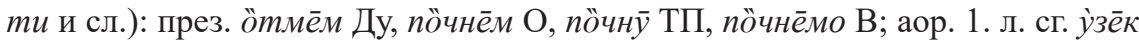

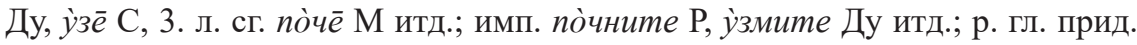
ӱзо Ду, ӱзеела М, пӧчёли С, ӧтеели Си и сл.; трп. прид. ӧтетто Ц, ӱзёто В. Исп. и двојак през. гл. на -пети (типа попети): пӧпнее се $\mathrm{P}$, пӧпнеем се Т, прӥпнеемо го̀веда $\mathrm{B} /$ nòneъy $\bar{c}$ се на̀ кућу $\mathrm{B}$.

${ }^{14}$ У Драгачеву је засведочено и у̀вйђем (Ђукановић 1995: 156), а у Полимљу и уни́ћu, уेнишо̄ (Николић 1991: 433). 


\section{2) Глаголи II врсте}

17. а) Засведочени су следећи облици гл. (-) бр иј ати (се): през. брй’е се

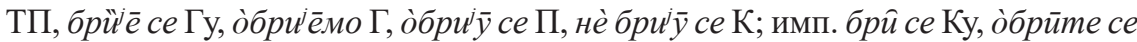

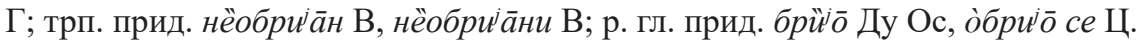

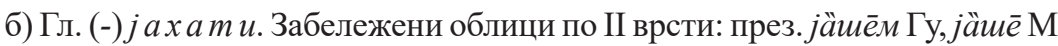

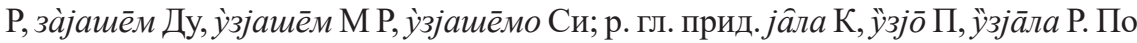
VI врсти налазимо: р. гл. прид. jäщu'o ко̀ња М, гл. прил. садашњи јӓше̄ћu M C.

в) Чује се стандардно ка́зати Ду С, али је обичнија форма ка́сти Вр Гл

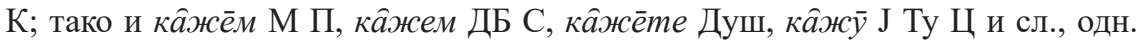
кámћy Ду С, кámћe ти се сáмо Во, кámћемо ДТ, кámћeme К, штӓ ка̂m В. Говори се ма̂ме̄ Д, маิшӯ ГС, а исп. и занимљиво (ако мӧш) ма́шати Д, са вероватно аналошким $и$ у инфинитиву.

г) Редовно је мйрише̄ Вуч Гу, мйришӯ М и сл.

д) Гл. (-) $m$ ка т и. Типична и (парадигматски) готово комплетно засведочена је промена по II врсти. Навешћемо потврде презента и императива: през. тке̂м Вуч Гу К ТП Ци, ткеิш Св Ц, тке̂ Вр Гл К ТП, тке́мо М Р, ткүิ В Вр Гл; исп. и йзаткём Ву, ѝзатке̄ Вр Гл, ѝзаткёмо Гу Ду, иेзаткӯ К Ц; имп. ткиิ Г М, иза̀тки К, проेтки Р. У Драгачеву је засведочено и ткаิм Вуч, тка́мо Ду Ос; овакви ликови спорадично се чују и у полимским насељима (Николић 1991: 447). У подринским насељима налазимо и че̂м Г Си, че́мо Ци, што србијански подрински појас чини оделитим унутар западносрбијанског ијекавског комплекса, приближавајући га пивско-дробњачким (Вуковић 1938-1939: 482) и источнохерцеговачким (Пецо 1964: 161) корелативним приликама. Нетипично и усамљено ткӓјӯ ДБ прилази промени по VI врсти.

18. Гл. же ет и. Инфинитивни облици имају двојаку основу: (-)же- и (-) жье-: инф. жёти Гл, на̀жети Г; аор. по̀же К, по̀жесмо М; р. гл. прид. жёо Р, жёли Д М; - инф. жъёти Св Ц, пожжети Го; аор. пожњесмо Го; р. гл. прид. жъёла Г пожњели В. През. облици су углавном на -жъ-: през. жњеем Вр Гл, жъе̂ се ТП, жье̂ $\mathrm{J}$ К, жње́мо ДТ М, нӓжње̄мо Си; имп. жњй Д, на̀жњите Г, по̀жьи Ду. Ликови са основом жањ- (нпр. жӓње̄ Д, жӓъеемо Р) чују се спорадично у нашим севернијим идиомима. Овлашно узевши, модел жети - жњем својствен је целом подручју, а образац жети (жњети) - жњем само полимским и подринским говорима.

С друге стране Дрине, у босанским подринским идиомима, заступљен је модел жёти - жӓъеем (исп. Ђукановић 1983: 254; Симић 1978: 84).

19. Различите основе затичемо и у през. гл. (-)слати: (-)щаљ- (у простог гл. и шиљ-) и (-)щљь-: шӓљеем С Св; шйљеем Ду, шйљьеемо Му / шљьеем Го;

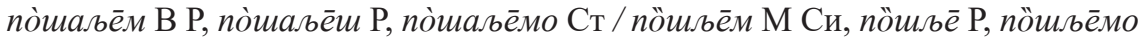


С Ст, пӧшљу шљь- (Николић 1991: 448).

20. За однос шапутати / шаптати исп. аор. сама̀nтаме се нёшто $\mathrm{B}$, през. шӓпће̄ $\mathrm{C}$, имп. ша̀nни ми $\mathrm{B}$.

21. Гл. (-)сисати потврђен је само у ликовима пӧсё Ду К, пӧсуे Р, по̀сали К.

22. Мањи број забележених глагола има презентске облике (односно понеки од њих) и по II и по V врсти: пљёште̄ Г Ра / спљѐска̄ га о̀час $\mathrm{B}$; йште̄

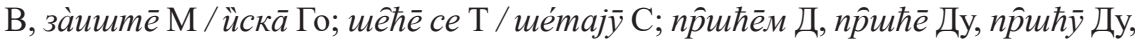

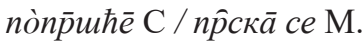

23. Само по II врсти јављају се и следећи презентски облици: бимшеемо

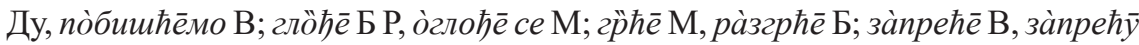

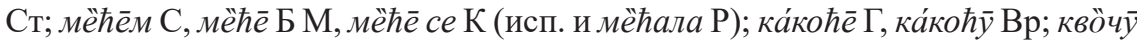

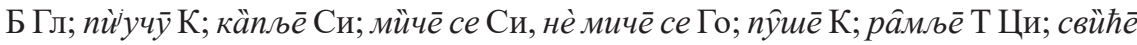
Ду, pàcвиће̄ се Си.

\section{3) Глаголи III врсте}

24. Глаголи ове врсте добро чувају инф. основу на -ну-: брйнути Св, брйнули М Ос, ви́кнула Ду, ја ви́кну нӓ њега̄ Го, гйнули ДТ, кре́нути Вр, окре́нули ДТ Ј, огр́нула, разми́нули се Ст Ц, разми́нуше се К, сва̀нуло Гу, осва̀нули ТП, ћӱшнула В итд.

25. Појединачне напомене. а) Засведочени примери трпног придева имају стандардне облике: за̀кре̄нут М, на̀крёнӯm Гу, о̀дмакнутто Д, ра̀змакнутте $\mathrm{M}$.

б) Доследно се чува основа -cma- у инфинитивним облицима: за̀стала Ду, на̀стало О, на̀стала Ду, о̀стати Г, о̀сто̄ П $\mathrm{P}$, ̀ेстала $\mathrm{J} \mathrm{T}$, nòcmō Ду, са̀стали се $\mathrm{P}$ итд.

в) Говори се сӓго̄ ce $\mathrm{B}$, нӑге̄ла се Р; исп. и нӓгнӯто Си.

26. О односу према конјугацији гл. других врста. Овде ћемо представити засведочене глаголе који се обично сврставају у гл. III врсте, али поједине облике имају и по некој од других гл. врста.

аа) Гл. сложени са -гинути и -кинути имају облике аориста и по III и по І врсти: пӧгинӯ М, ѝзгинуше $\mathrm{B}$, скйнуше $\mathrm{M}$; по̀zибо ра́де̄ћи $\mathrm{B}$, по̀гибе Ду, скӥде К Ст, скӥдоше Ду, прѐкиде Т, прѐкидоше Си. Глаголи на -кинути обичнији су по I врсти.

аб) Двојако је и у гл. на -снути, и то како у аористу тако (бар код неких) и у р. гл. придеву: аор. оттискоше ДТ $\mathrm{J}$, пиште Б К, на̀прште М / зӓкиснӯ $\mathrm{B}$, на̀прснуше Ду; р. гл. прид. пр̈сла Б Р, пр̈сли Р, за̀кисло В M / за̀киснула Г Р, по̀киснуло $\mathrm{P}$, на̀прснула $\mathrm{B}$. 
ав) Неуједначено је и у облицима аориста гл. (-)кренути: ѝскретоше В, за̀кретоше Ду, о̀крете се ДТ / искре́нуше Ст Ц, ӧкрёну се К; исп. и крёте В.

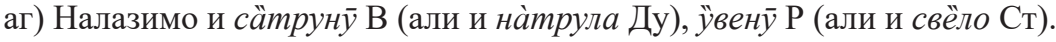

б) У примеру Моें о̀тац клёчй па нйкад у̀стати ДТ, през. облик прилази VI врсти.

Имамо, међутим, и клёкнём В, клёкнӯ Р.

в) Глагол метнути има облике и по III и по VI врсти: през. мётнеем К, мётнеемо В ТП, аор. мётнуше О, имп. мётни Ду, р. гл. прид. мётнула Во, мётнули П; през. мётӣи Рош, мётӣмо Вр РБ, мётӣ се Рош, имп. мёти Рош, р. гл. прид. мётила J.

Говори се, међутим, и тӥрӣм Ду, тӥрила К, стӓвила Б итд.

г) Раздвојеност по врстама (опет по III и VI) уочавамо и у засведоченим

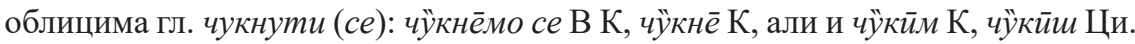

27. Посебан осврт (и брижљивије сагледавање) заслужује следеће запажање. Посве је необична и неочекивана секвенца -ни- наместо стандардног -ну- у примерима: ја̂ зйнила Ду, кре́нили Ос, окре́нити се В, окре́нила се С, по̀гинићеш $\mathrm{P}$, прѐкинило К, скӥнићеш Р, укинили К. Сви наведени примери забележени су на подручју Ужичке Црне горе. Секвенца -ни- представљене ликове измешта из III у VI врсту. Ликови типа кренити унеколико (не и битно!) релативизирају уверење о стабилности секвенце -ну- у инф. основи глагола III врсте на подручју Ужичке Црне горе.

28. Излагање о „глаголима III врсте” завршићемо интересантном комбинаториком. Ако некима од претходно наведених ,дублета” додамо одговарајуће примере са -ни- (додуше, ареално ограничене и не нарочито фреквентне) добићемо занимљиве ,триплете”, исп.: по̀гибоше (I) / ѝзгинуше (III) / по̀zинићеш (VI); скӥдоше (I) / скӥнуше (III) / скӥнићеш (VI).

\section{4) Глаголи IV врсте}

29. У већини засведочених примера глаголи на -ива- имају облике презента и императива по овој врсти, тј. на -yј(-): вѐзујёш М, дочѐкуе С, дочѐку'ёмо

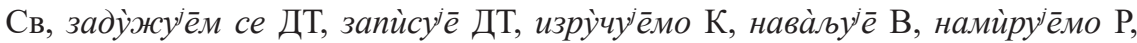

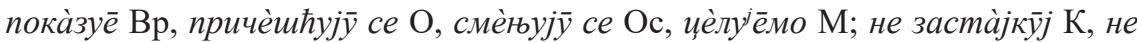
пока̀зӯjmе $\mathrm{P}$, не ува̀љь̄j Ц.

Облици по $\mathrm{V}$ врсти релативно добро су заступљени само у говору

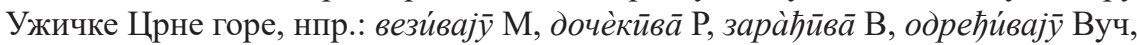

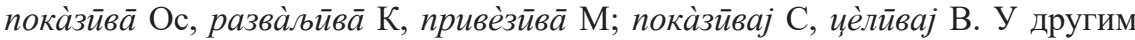
западносрбијанским ијек. идиомима (подринским, моравичким, драгачев- 
ским, полимским) образац наређивати - наређивам је слабије заступљен (в. Николић 1991: 451).

30. Гл. на -ава- који у књ. језику иду по IV врсти најчешће имају такве облике и у западносрбијанским ијекавским говорима, нпр.: през. дӓंём Вр,

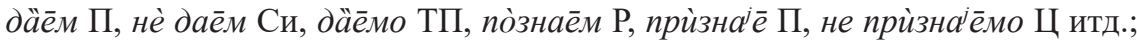
имп. да́и Б М, не да́и М, прода́и Гу. Поред гл. познавати са истим видом се јавља и гл. познати: по̀зна̄м Ду, нё позна̄м Р. По V врсти имамо: даิва̄ ђёци Ду, ѝздавва̄м К, упо̀зна̄ва Ду. Форме типа давам, познавам знатно су чешће у неким херцеговачким и црногорским говорима (исп. нпр.: Вушовић 1927: 58; Пецо 1964: 150; Пижурица 1981: 161).

И по V и по IV врсти (према различитим облицима инфинитива, као и у

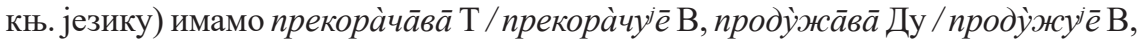
украша́ваје̄ $\mathrm{J} /$ укра̀my' $\overline{\mathrm{T}} \mathrm{T}$ (исп. и интересантно украси́вало се К). Стандардни су

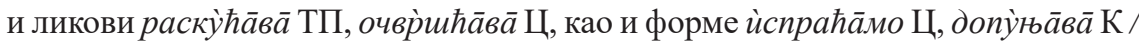
на̀nӯґам Си (али не и испра̀ћа̄вамо Р). Књижевнојезичко обличје препознајемо

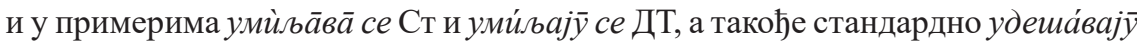
В има своје (свакако интересантније) дијалекатске пандане у ликовима $\grave{y} \bar{e} ш \bar{a}$

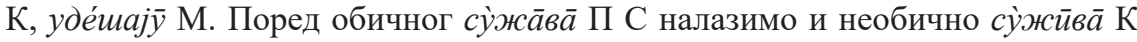
(настало, вероватно, аналогијом према фреквентним видским антиподима типа суিзй се В, су́зили Ци, су́зијо К, па и су́жи'о К).

31. Трпни придев. а) Глаголи са општим делом кри, ли, ши имају облике на -вен: открѝвен Ду, покрйвен Б, покривѐна $\mathrm{M}$, прекрѝвен Ду $\mathrm{O}$, сакривѐни В К, пришѝвен Б Ц, ко саливѐна В. Тако је и у гл. на -ути: изу̀вен Ду, изувѐни М, обу̀вен Ду.

б) Двојако је у гл. са основом пи и ви: испи'ѐна М, непопи'ѐно С;-завй'ен Ду, обавиंѐне Ц, развйंен К Ц; йспӣта В; - сӓвйта Ц.

в) Гл. са основом би имају облике на -ијен и -ивен: бѝен $\mathrm{P}$, би'ѐни М, избйंен М, убйंен Ду М ТП; побивѐни Ос, пробивѐна $\mathrm{P}$, сабивѐна Т.

У Ужичком Подрињу засведочено је и сӓвйт (Тешић 1977: 228), а у моравичком крају и ликови типа бјён, бје́на (Николић 1972: 646). Облици трп. прид. на -јен далеко су обичнији у западносрбијанским ијекавским говорима јужно од Златибора; исп. Николић 1991: 452-453. ${ }^{15}$

32. О ј ош не к и м г л. IV в р с т е. а) Гл. ждити имамо само у усамљеној композити прӥжди'е̄м (вӓтре̄ мӓло) 3.

${ }^{15}$ Облици трп. прид. на -јен веома су чести и у неким околним сродним говорима, исп. нпр. Вуковић 1938-1939: 74; Пецо 1964: 150; Пижурица 1981: 157. 
б) Облик гл. сликовати се у изговореном стиху А̀jде, драิги, да се слӥ$\kappa y^{j} \bar{e}$ мо РБ неаутохтон је, несвојствен „обичном” говору; овде је слйка̄ се Р, слӥкаме нас К. ${ }^{16}$

в) Доследно је: чӱо К, чйо̄ Ду (никад * чуно или сл.), чйла Ду, чйंе̄м Б ТП и сл.; кази́вати В (никад *каживати или сл.), ка̀зуе̄ М, ка̀зује Ду и сл.; кйём Ц, за̀куе̄ Р и сл.

\section{5) Глаголи V врсте}

33. През. облици гл. дати, знати и имати јављају се чешће (а одричне форме редовно) без форманта $\partial:$ даิм В, нѐ да̄м $\mathrm{C}$, да́мо Ц, нѐ да̄мо ДТ, нѐ

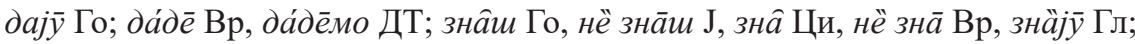
зна́де̄м Го, зна́де̄me Вуч; ѝма̄м Вр, ѝма̄мо $\mathrm{J}$, има́мо Го, ѝма̄me Го К, има́me Вуч; има́де̄м Г. Говори се неิма̄м Гл, неิма̄мо Вр. Исп. и композите до̀да̄м Го, проेда̄мо Ц и сл.; до̀зна̄м Б К, са̀зна̄м К и сл.

У Ужичком Подрињу засведочене су и форме типа на̂и, на́деш (Тешић 1977: 232). У србијанском Полимљу поред чешћег немам јавља се и облик нем, као и ликови типа нёं $м \bar{a}, e^{\prime}$ мали (Николић 1991: 455). Свуда се могу чути и презентске форме типа дӓднемм Вр, знӓднём К Ст, ѝмаднём ДТ.

34. По V врсти иду и глаголи на -гнати (-гњати): през. до̀сна̄м Вр Гл

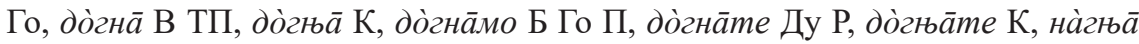
К, на̀зна̄мо М С, нагна́мо В Г, са̀zна̄ Ду; имп. до̀zна̄j Ду, до̀zна̄jme J Р, са̀zна̄j Ду; р. гл. прид. до̀снале М; трп. прид. дӧгна̄mи С. Ликови на -гњати нису засведочени у србијанским идиомима јужно од Златибора (Николић 1991: 454).

35. Из мноштва засведочених глагола који иду по V врсти, издвојићемо и следеће:

гл. (-)глёдати (се): инф. глёдати Го; аор. глёдаше $\mathrm{P}$, зллёдаше се $\mathrm{M}$, за̀гледаше се О; р. гл. прид. глёдо̄ Вр ДТ, по̀гледо̄ П Р итд.; през. глёда̄м С Ц, глёда̄ Вр Гл, нѐ гледа̄ Ду

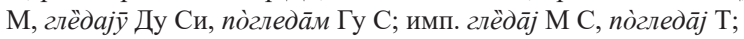

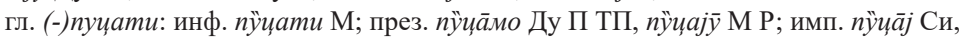

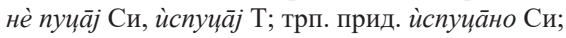

гл. (-)рачунати (се): инф. израчу̀нати $\mathrm{B}$; аор. рачуेнаше $\mathrm{B}$; през. рачу̀на̄ ДТ Ј, рачу̀нъ $\bar{a}$

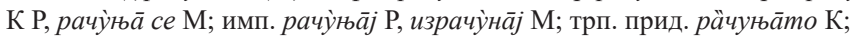

гл. (-)свађати се: през. нѐ свађа̄м се В, свӓђа̄ш се Ду, свӓђајӯ се ДТ, по̀свађајӯ се $\mathrm{P}$; аор. свӓђаше се С; р. гл. прид. свӓђо̄ се Т, свӓђали се Р, по̀свађали се ТП;

гл. (-)тјёрати (се): инф. ћёрати ДБ, ѝшћерати Си, за̀ћерати Ц итд.; аор. зӓћера̄ га К, ѝmћераше ДТ, по̀ћераше Т Ц, на̀ћераше С и сл.; р. гл. прид. ћёро̄ Ду, ѝшћерали М, ћёрали се К и сл.; през. ћёра̄м $\mathrm{M}$, ѝшћера̄м $\mathrm{B}$, по̀ћера̄м $\mathrm{C}$, ра̀шћера̄мо С и сл.; имп. ћёра̄j Ду, ̀̀mћера̄j $\mathrm{M}$, по̀ћера̄j ДТ и сл.; трп. прид. за̀ћера̄н Куш, ра̀шћера̄ни К;

гл. (-)чекати: инф. чёкати К Си, ѝшчекати ДТ С, прѝчекати С; р. гл. прид. чёко̄ К, чёкала Ц, чёкали Т Ц и сл.; през. чёка̄м Б ДБ, чёка̄ми О П, чёка̄мо Гу, са̀чека̄мо Ст и сл.; имп. чёка̄ј Б Гу, нѐ чека̄j Ду Р, са̀чека̄j $\mathrm{M}$ и сл.

\footnotetext{
${ }^{16}$ Облици гл. сликовати веома су чести у централној Шумадији (Реметић 1985: 356).
} 
Исп. и: беа̀ра̄ Си; сапу̀њ $\bar{a}$ Ц, нӓсапуњо̄ Ц / насапу̀на̄м⿻ В.

Као што се из представљене грађе види, гл. гледати, као ни у другим сродним говорима, не прелази у VI врсту; у 3. л. пл. през. доследно је -аjy (не и -ау или -аје).

Вуково рачунити није засведочено у говорима северно од Златибора; спорадично се јавља у јужнијим србијанским ијек. идиомима (Николић 1991: 455).

\section{6) Глаголи VI и VII врсте}

\section{а. О појединим облицима}

36. У 3. л. пл. през ента гл. VI и VII врсте јавља се, углавном, стан-

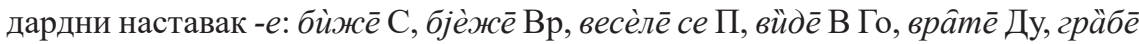

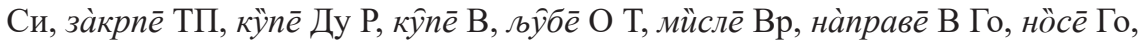
по̀праве̄ $\mathrm{M}$, ра̀зва̄ле̄ итд.

Ликови са аналошким -y у 3. л. пл. неједнако су заступљени у различитим деловима западносрбијанског ијекавског комплекса. У подринским, ужичким, драгачевским и моравичким насељима овакви облици су скромно засведочени;

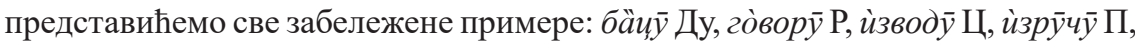

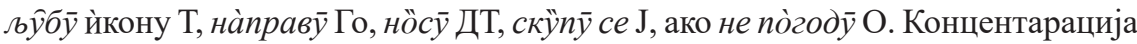
оваквих ликова је изразита једино у централним полимским селима, углавном у околини Пријепоља и Бродарева (Николић 1991: 457-460). ${ }^{17}$

37. Гл. прилог садашњи има форме на -ећu и -yћu. Ликови на -ећu изразито преовлађују у подринским и ужичким насељима (углавном је вйсёћu Р, ѝзлазе̄ћu В, нӧсёћи Б и сл.; ретко с'еду́ћи М и сл.). Двојство -ећи / -yћu, тј. мање-више равномерна употреба, својствена је драгачевским и полимским селима (исп. Ђукановић 1995: 153; Николић 1991: 460). ${ }^{18}$

38. Трпни придев. а) Глаголи VI врсте имају доследно стандардни наставак -ен: граิђен Б, за̀гра̄ђено $\mathrm{M} \mathrm{T}$, оेрра̄ђено Г $\mathrm{P}$, жёњен $\mathrm{M}$, ѝженени $\mathrm{B}$, о̀женен Д С, за̀ба̄чено $\mathrm{C}$, за̀nа̄љена $\mathrm{C}$, за̀послен Ц, за̀nослени $\mathrm{B}$ Ц, за̀nошљени Ду, за̀робљен К Т, за̀са̄ђене $\mathrm{P}, \grave{и з б а ̄ ч е н ~} \mathrm{M}$, провр́ћено К, на̀nаћена Ду, на̀са̄ђена К, нӧшено О, ѝзношено $\mathrm{B}$, оेдре̄ђени Ц, плаิћени $\mathrm{P}$, по̀nа̄љене К, по̀са̄ђен Ду $\mathrm{P}$, ра̀зва̄љена Ду $\mathrm{O}$, са̀стаљено С итд.

${ }^{17}$ Ликови типа нӧсу фреквентнији су у суседним црногорским и херцеговачким идиомима: за пљеваљски исп. Ћупић 1988: 93; за источноцрногорски Стевановић 1933/4: 86; за источну Херцеговину Пецо 1964: 151.

О приликама на ширем штокавском терену исп. Раметић 1985: 305-308.

18 У Љештанском (Ужичко Подриње) засведочена је необична (али индикативна!) форма лѐжајӯћu, која „показује да се у Љештанском губи језичко осећање за садашњи прилог” (Тешић 1977: 228). 
Интересантна су колебања у жењен/ожењен и у запослен, запослени/ запошљени (увек је, међутим, бѐспослен Г М или пак брѐспослен $\mathrm{P}$ ).

б) Код трпних придева гл. на -стити налазимо и -шћ-: кр̈шћено Ву, пйшћени Ду (а исп. и запу́шћело Р). Ипак, чешће је кр̈штен ДБ, кр̈штено Вр Гл, кёштени Р ТП (редовно је и критѐница Г М, критѐниу В), пӱштен Ду, пӱштени Ц. Само са -ић- имамо запрѐпа̄ићени К П, упро̀nа̄шћен В К М, упро̀па̄ићени Ду.

в) Примери са -ит (бӓцйт и сл.) нису својствени говорима северно од Златибора; у полимским селима јављају се ретко (Николић 1991: 461). У синтагмама јѐдно мјёсто зӓклонито В и у̀склоните сто̀лице Ду облици на -ит су прави придеви.

\section{б. О неким глаголима и скупинама глагола}

39. Глаголи на -итu/-uм. а) Глаголи на -ни- не прелазе у III врсту; дакле,

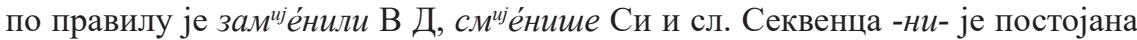
и у у̀сни'о Г, у̀снила ТП (у значењу 'видети, доживети у сну, сањати'). По III врсти (као и у многим другим говорима, и не само сеоским) иде гл. извини́ти ce: изви́нула се Ду П, изви́нули се В. Нарочито су заступљене форме $\partial(a)+$ презент, тј. конструкције $\partial$-йзвйнеш $\mathrm{M}$, да иेзвйнеш С и сл., као ознаке извесног снебивања у „осетљивим” сегментима дескриптивних и наративних пасажа.

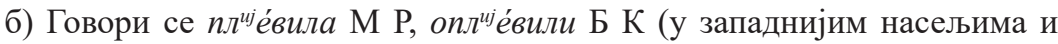
пље́вйм Г).

в) Чешће је сnácumи Г М T (VI врста) него спа́сти ТП (І врста), бро̀ити Б Р Ц (VI врста) него бро̀јати В Г (VII врста, чују се у централним и западнијим насељима).

г) По VI (никад по IV!) иду облици гл. сломити: през. слӧмйм J T, слӧмй Ду ТП, аор. сло̀мише Ду, трп. прид. слӧмљен Ј, слӧмљено Си Т.

40. Глаголи на -јети/-им. а) Гл. видјети. Прво л. презента редовно (и свуда) гласи видим. За скретање пажње (и без гл. значења) употребљавају се ликови виш и (још чешће) ищ: да̀ виш Г П, да̀ иш В J C (само у конструкцијама са $\partial a$ ). Засведочени облици аориста: 1 . л. сг. вйђок Ду У, вйђо Г Ц, нѐ виђок В, нѐ виђо Ц; 2. и 3. л. сг. вӥђе П Р ТП, 3. л. пл. вӥђоше О Р, нѐ виђоше М. Имп.: вйди Ду Р С и вйђи М Т (не и *ьиђ); исп. и вйђиде Ду Ц, вйде̄ О, као и полимско вйдни ђёцу (Николић 1991: 466).

б) Засведочени су следећи облици гл. (-)зрети: презент: 3. л. сг. зриิ Ду

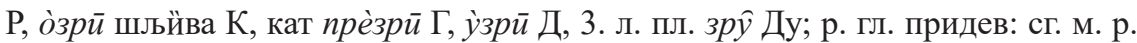
зрйіо Д Ц, са̀зри'о $\mathrm{B}$ / са̀зрео Д; сг. ж. р. до̀зрела $\mathrm{O}$, прѐзрела К. 
в) Гл. шутјети / ћутати. Облици са (-)щи иду по VI, док облици са (-)ћ (нешто чешћи) и по VI и по VII врсти: инф. шу́ћети $\mathrm{P}$, шу́тити Г, аор. шу́ће M, заши́ћеше Р, р. гл. прид. шу́mи'о Ду, уши́ћели Р, през. шу́тӣм Г, шу́mй ДТ, имп.

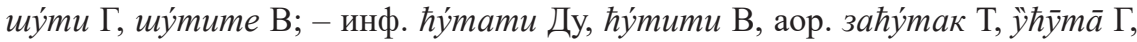
заћу́mише ДТ, р. гл. прид. ћу́тиंо ДТ, през. ћу́mӣм Ду, заћу́mӣмо В, имп. ћу́mи Д Ра, ћýme Р (=ћýmume ТП).

41. Гл а го л и VII в р с т е. а) Гл. бјежати нема основу бјег-: инф. бјѐжати Б ДБ Р (исп. и полимско бјѐжат), ${ }^{19}$ бѝжати Г М; р. гл. прид. бјёжо̄ Б Ду Ј П ТП, бӥжо̄ Р, бјёжа̄ли Б Г Ду О, бёжа̄ли Ду, бйжа̄ла Ц; през. бјѐжӣм М Си, бѝжӣм К Р Ц, бјежи́мо М Р, бјежи́те М, бижи́мо Б, бјѐже̄ Г К, бѝже̄ С Ц итд.

б) Говори се за̀сnӣм Ду М Р, за̀сnӣu Б Ду и сл. ${ }^{20}$

в) Поред изразито фреквентних (и свуда присутних) ликова типа ста̀јати Г ТП, стӓjō В, стӓjа̄ла Г Р, стӓја̄ле В, стӓjа̄ли Ду Ц и сл., у Ужичком Подрињу и западнијим селима Ужичке Црне горе налазимо и сто̀jати Г, стӧја̄ли ДТ Ц и сл., ликове у којима долази до делимичног аналошког изједначавања инф. и през. основе. ${ }^{21}$

\section{III. ЗАКЉУЧНЕ НАПОМЕНЕ}

42. У завршним пасусима рада овлашно ћемо се осврнути на изложене и сагледане глаголске категорије; најпре ћемо сажети утиске о њиховој појавној (не)разноликости, степену заступљености и ареалној (не)условљености, а потом успоредити маркантнија уочена стања са корелативним приликама у сродним (углавном додирним) дијалекатским областима.

43. На целом подручју испитиване говорне области очитују се (и) следеће особине сагледаних глаголских разреда:

- двојство у изићи/изаћи (однос $u / a)$; т. 11;

- ликови са -же $\leftarrow$ *-ге у парадигми гл. моћи (може и сл.); т. 2;

- модел жети - жњем (т. 18);

- ликови са аналошким -y у 3. л. пл., нпр. раду и сл. (изразитије заступљени само у централним полимским насељима); т. 36;

- ликова типа ста̀jати, стӓjō, стӓjа̄ла (т. 41);

- образац наређивати - наређивам (повишене фреквенције само у ужичким селима); т. 29;

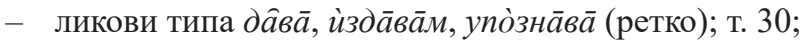

- облици на (-)щаљь-, тј. тип по̀шаљеем, по̀mаљеет (т. 19).

${ }^{19}$ Исп. Николић 1991: 468.

${ }^{20}$ Форма зӓспём засведочена је само у „прелазном говору” полимске области (Николић 1991: 468).

${ }^{21}$ Тешић 1977: 200 cmàjamu / cmòjamu. 
44. Разведеност ареално условљених особина непосредни је одблесак испреплетености одговарајућих изоглоса, које браздају подручје на све стране, чинећи обрисе дијалекатских ареала порозним, а закључке несигурним и условним. Стога крајње опрезно повлачимо следеће раздеоне линије.

a) Особине својствене севернијим и источнијим сегментима западносрбијанског ијекавског подручја (грубо узевши, насељима што се простиру северно и источно од Златибора):

- облици на (-)шљь- типа шљеем, пӧшљеем (т. 19);

- форме типа на̂ш, на́деш (само у подринским селима); т. 33;

- ликови на -гњати (до̀гњ $\bar{a}$, до̀гњ

- примери типа зйнила, кре́нили (само на подручју Ужичке Црне горе); т. 27;

- тип стојјати, стӧја̄ли (у Ужичком Подрињу и западнијим селима Ужичке Црне горе); т. 41.

б) Особине својствене јужнијим областима западносрбијанске ијекавске плохе (овлашно узевши, селима распоређеним јужно од Златибора):

- примери с нејотованом основом типа приิдемо, сйде, одн. ѝзйдём (ѝзйдем), ѝзйде̄u (као и сасвим необично наิде, проิде̄); т. 11;

- облик немм, као и ликови типа нёं ма̄, не́ мали (поред чешћег немам и сл.); т. 33;

- Вуково рачунити (ретко); т. 35;

- трп. прид. са -ит - бӓцйт или сл. (ретко); т. 38.

в) Однос сићи/саћи заступљен је у подринским идиомима, северозападном делу Ужичке Црне горе и, спорадично, у драгачевској и полимској области (т. 11).

г) Облици са -ре $\leftarrow$-же маркантно су обележје јужнијих и западнијих западносрбијанских херцеговачких идиома: србијанског Полимља, рачанског краја, западнијих насеља Ужичке Црне горе и србијанских подринских насеља (т. 2);

д) Модел жети/жњети -жњем својствен је полимским и подринским говорима (т. 18).

45. Ако упоредимо најмаркантније сагледане особине са корелативним приликама у сродним (углавном оближњим) народним говорима, приметићемо многе (углавном очекиване) сличности, али и осетне (каткад и неочекиване) разлике. Уочићемо, нпр., да је немали број изражајних херцеговачких дијалектизама (облика, алтернација) или слабо заступљен (нпр. образац наређивати - наређивам, ликови типа давам, познавам, форме реда раду, љубу и сл.) или није посведочен (нпр. имп. *виђ, трп. прид. *чуно, инф. *обаћи или пак *каживати и сл.). Унеколико изненађује и одсуство модела *жети-жањем, 
преовлађујућег већ у суседним босанским идиомима. С друге стране, донекле је неочекивано присуство ликова типа зйнила, кре́нили, несвојствених већини херцеговачких говора.

Сагледане у широким оквирима херцеговачких прилика, дијалекатске специфичности представљених конјугацијских разреда су дијалектолошки неминовне и релативно ретке. Западносрбијанско говорно подручје густо је уткано у структуралну потку своје матице - пространог и разуђеног источнохерцеговачког дијалекта.

\section{ЛИТЕРАТУРА}

Вуковић 1938-1939: Ј. Вуковић, Говор Пиве и Дробњака, Јужнословенски филолог, XVII, 1-114.

Вушовић 1927: Д. Вушовић, Диалекат источне Херцеговине, Српски дијалектолочки зборник, III, 1-71. + карта.

Ђукановић 1983: П. Ђукановић, Говор села Горње Цапарде (код Зворника), Српски дијалектолошки зборник, XXIX, 191-292.

Ђукановић 1995: П. Ђукановић, Говор Драгачева, Српски дијалектолошки зборник, 1-239. + карта.

Марковић 2011: С. Марковић, Говор Ужичке Црне горе, Српски дијалектолошки зборник, LVIII, 337-670.

Марковић 2012: С. Марковић, Границе ијекавских говора у западној Србији, Српски дијалектолошки зборник, LIX, 387-484.

Марковић 2013: С. Марковић, О говору села Придола код Бајине Баште, Годишъак за српски језик, год. XXV, бр. 13, Филозофски факултет у Нишу, 329-347.

Николић 1972: М. Николић, Говор села Горобиља (код Ужичке Пожеге), Српски дијалектолошки зборник, XIX, 616-746.

Николић 1991: М. Николић, Говори србијанског Полимља, Српски дијалектолошки зборник, XXXVII, 1-548.

Пецо 1964: А. Пецо, Говор источне Херцеговине, Српски дијалектолошки зборник, Београд, XIV/1, 1-200.

Пижурица 1981: М. Пижурица, Говор околине Колашина, Титоград: ЦАНУ, Посебна издања, књ. 12.

Реметић 1985: С. Реметић, Говори централне Шумадије, Српски дијалектолошки зборник, XXXI, XIX + 555. 
Симић 1972: Р. Симић, Левачки говор, Српски дијалектолошки зборник, XIX, 1-618. + карта.

Симић 1978: М. Симић, Говор села Обада у босанском Подрињу, Српски дијалектолошки зборник, XXIV, 1-124.

Стевановић 1933/4: Михаило Стевановић, Источноцрногорски дијалекат, Јужнословенски филолог, XIII, 1-128.

Стевановић 1981: М. Стевановић, Савремени српскохрватски језик (Граматички систем и књижевнојезичка норма) I, Београд: Научна књига.

Тешић 1977: М. Тешић, Говор Љештанског, Српски дијалектолошки зборник, XXII, 159-328. + карта.

Ћупић 1977: Д. Ћупић, Говор Бјелопавлића, Српски дијалектолошки зборник, XXIII, IX +226.

Ћупић 1988: Д. Ћупић, Основне особине говора Пљеваља, Гласник Одјељења умјетности ЦАНУ, 8, Титоград, 79-107.

\section{ON THE MORPHOLOGICAL INTERFERENCE OF VERBS IN WEST-SERBIAN IJEKAVIAN SPEECHES}

\section{Summary}

The essay delves into the prominent specificities of conjugational types in West-Serbian Ijekavian speeches. The relevant dialectal corpus is analyzed with the aid of descriptive and contrastive analytical methods. The examined dialectal region is scrutinized from different angles: lexical representation and morphological dispersion of verb categories, intrinsic differentiation of fields, comparisons to correlative instances in other kindred speeches. The carried-out analyses suggest the following conclusions. A considerable number of conspicuous Herzegovian dialecticisms (forms, alternations) is either of low frequency (e.g. pattern наређивати - наређивам, type forms давам, познавам, type forms раду, љубу, etc.) or is not given evidence at all (е.g. imperative виђ, past participle чуно, infinitive обаћи, каживати, etc.). On the other hand, the presence of types зинила, кренили, etc., is somewhat unexpected, uncharacteristic of the greatest number of related speeches. Nevertheless, all in all, it can be ascertained that West-Serbian Ijekavian region is not at variance with the exemplary Herzegovian average.

Key words: verbs, conjugation, correlations, Ijekavian, Herzegovian. 